\title{
POTENSI LAHAN DAN TENAGA KERJA TEHADAP PEMANFAATAN AIR DI DAERAH IRIGASI KECAMATAN KUPANGTENGAH KABUPATEN KUPANG-NTT.
}

\author{
Maria Soik Manehat (1) , Marthen R. Pellokila (1,2) ${ }^{\text {I.N.Prijo Soetedjo }}{ }^{(1,3)}$ \\ (1) Program Magister IImu Lingkungan,Univer sitas Nusa Cendana,Kupang \\ Email: manehatmaria@gmail.com \\ (2)Fakultas Peternakan,Universitas Nusa Cendana, Kupang \\ (3)Fakultas Perikanan, Universitas Nusa Cendana, Kupang
}

\section{ABSTRAK}

Tujuan dari penelitian ini (1) menganalisa ketersediaan air, lahan dan tenaga kerja yang dimanfaatkan untuk usahatani padi sawah. (2) Untuk menganalisis efisiensi pemanfaatan air, lahan dan tenaga kerja terhadap produksi usahatani padi sawah di Kecamatan Kupang Tengah. Pengambilan sampel dilakukan di desa Noelbaki yang merupakan daerah irigasi yang memiliki lahan potensial khususnya padi sawah. Penentuan responden menggunakan metode acak sederhana, yakni diambil $10 \%$ dari populasi petani padi sawah, yakni sebanyak 50 orang. Untuk penga mbilan sampel peneliti hanya menfokuskan petani yang memanfaatkan air dari saluran irigasi untuk usahatani padi sawah. Berdasarkan hasil analisis efisiensi pemanfaatan air pada usahatani padi sawah belum efisien (nilai NPM xi/Px $<1$ ). Efisiensi pemanfaatan lahan usahatani padi sawah masih dapat ditingkatkan karena belum efisien (nilai NPMxi/Px $>1$ ). Untuk pemanfaatan tenaga kerja untuk usahatani padi sawah di lokasi penelitian belum efisien (nilai NPMXi/PX > 1). Ketersediaan air, lahan dan tenaga kerja di lokasi penelitian cukup mendukung pengelolaan usahatani padi sawah. Hasil analisis pemanfaatan air di lokasi penelitian tidak efisien. Untuk itu petani harus mengurangi jumlah pemakaian air, sedangkan pemanfaatan lahan masih harus ditingkatkan. Petani harus dapat memperluas lahan garapan yang dimiliki untuk usahatani padi sawah. Pemanfaatan tenaga kerja juga belum efisien, sehingga petani harus mampu memanfaatkan tenaga kerja yang ada untuk aktif dalam kegiatan usahatani padi sawah.

\section{Kata kunci : padi sawah, efisiensi, produksi}

\section{ABSTRACT}

The aim of this research was 1). to anaiyze the availability water, field and workers which use to produce rice. 2) to analyze efficiency of water using, field and workers for rice production in Central kupang Distric. Sample has taken in irrigation area at Noelbaki village which has potential field for rice production. Simple random method was used to select 50 farmers from $10 \%$ population of farmer. Farmers that use as sample are farmers that use water from irrigation canal for rice farming. The result for water efficiency is not efficient ( NPMxi/Px > 1). The same result is also show forworkers, workers employing is not efficient (NPMXi/PX > 1). The availability of water, field, and workers in research area are enough to support rice production. For water inefficiency using, farmer must reduce the quantity of water, and for filed efficiency must be increase. Farmer must expand the field utilizing and for worker employing is also not inefficiency, in that case farmers must employing the workers to increasing the productivity actively.

Key Words: Rice, efficiency, productivity

\section{PENDAHULUAN}

Sektor pertanian berperan dalam pembangunan terutama pada negara yang sedang berkembang. Peranan sektor pertanian tersebut dapat dikategorikan ke dalam tiga hal. Pertama, pertanian pada umumnya merupakan sektor dominan di kebanyakan negara berkembang, dilihat berdasarkan proporsi gross domestic product (GDP) yang dihasilkan dalam sektor ini atau menurut sumbangannya terhadap penyerapan tenaga kerja total atau keduaduanya.Kedua, pertumbuhan sektor non pertanian di negara berkembang sangat tergantung pada peningkatan penyediaan pangan yang mantap karena itu menyebabkan inflasi dan biaya upah yang rendah. Ketiga, sektor pertanian menyediakan lapangan kerja bagi angkatan kerja (Rencana Pembangunan Pertanian 2005-2009).

Pertumbuhan sektor pertanian yang semakin melamban menyebabkan beberapa dampak, selain penurunan kemampuan penyediaan pangan nasional, juga berdampak pada penyerapan tenaga kerja di sektor ini. 
Penurunan sektor pertanian disebabkan rendahnya produksi pertanian sebagai akibat dari rendahnya produktifitas lahan maupun tenaga kerja. Berbagai upaya kebijakan pemerintah telah dilakukan untuk menopang peningkatan produksi pertanian. Usaha-usaha yang dilakukan antara lain pembangunan irigasi, subsidi benih, pupuk dan pestisida, kredit usahatani dan pembinaan kelembagaan usahatani. (Bank Indonesia, 2008).

Sebagai salah satu upaya pemerintah dalam rangka memenuhi kebutuhan air irigasi permukaan di Kabupaten Kupang, Departemen Pekerjaan Umum melakukan usaha penyediaan air melalui saluran-saluran irigasi yang berasal dari sumber-sumber air. Fungsi dari saluran irigasi yakni meningkatnya persediaan air pada musim kemarau sehingga petani akan berusaha untuk memanfaatkan lahan yang tersedia. Untuk memanfaatkan lahan yang dimiliki, petani di lokasi sekitar saluran irigasi melakukan diversifikasi beragam tanaman yang ditanam secara monokultur. Jenis tanaman yang diusahakan pada musim hujan sejak awal bulan Desember sampai Mei yakni tanaman padi. Sedangkan jenis tanaman pangan yang diusahakan pada musim kemarau sejak bulan Juni sampai bulan Desember di lokasi ini dengan memanfaatkan air dari saluran bendungan tilong antara lain padi, jagung dan kacang-kacangan. Walaupun petani di sekitar daerah saluran irigasi sudah melakukan diversifikasi jenis tanaman, tetapi masih terdapat lahan potensial yang belum dimanfaatkan. Lahan yang dimanfaatkan yakni sebesar 84,890 ha atau sekitar $87,71 \%$ sedangkan lahan yang belum dimanfaatkan yakni sebesar 121 Ha atau sebesar 10,29\%. (Depertemen PU, 2002).

Selanjutnya tingkat produktifitas lahan khusus untuk tanaman pangan seperti padi, jagung, ubi kayu, ubi jalar, dan kacang tanah dari tahun 2006 hingga 2012 mengalami peningkatan yakni padi sawah sebesar $16,7 \%$, padi ladang $38,4 \%$, jagung $20,7 \%$, ubi kayu 30,6\%, ubi jalar 28,8\% dan kacang tanah 68\%, hal ini menunjukan bahwa petani mampu memanfaatkan air dari bendungan tilong untuk menggarap lahan potensial di sekitar saluran irigasi. Selanjutnya survei (2013) yakni dengan adanya bendungan tilong petani dapat melaksanakan usahatani tanaman pangan sebanyak 2 kali musim tanam dalam setahun.

Salah satu masalah yang dihadapi oleh petani di daerah tersebut adalah belum efisiennya lahan, ditandai dengan masih tersedianya lahan yang belum dimanfaatkan untuk usaha pertanian yakni sebesar 45 ha (Dinas Pertanian, 2013). Ada beberapa faktor yang menyebabkan belum efisiennya lahan yang dimanfaatkan petani yakni (1) rendahnya modal yang digunakan untuk membeli sarana produksi (bibit, pupuk, dsb) (2) rendahnya pengetahuan petani untuk mengusahakan jenis tanaman lain selain tanaman pangan, (3) rendahnya informasi pasar yang dimiliki petani sehingga petani tidak mengetahui jenis tanaman yang memiliki nilai ekonomis yang tinggi (Naisanu, 2009). Masalah lain yang nampak di lokasi penelitian, yakni belum efisiennya penggunaan tenaga kerja. Tenaga kerja merupakan salah satu faktor produksi yang berperan penting dalam suatu usahatani. Tenaga kerja berguna untuk mengelola sistem usahatani yang dijalankan, di mana petani selaku tenaga kerja dapat meningkatkan produktivitas lahan dengan menambah jenis tanaman yang diusahakan, meningkatkan intensitas jam kerja, meningkatkan pengetahuan budidaya termasuk pemanfaatan air irigasi untuk usahatani padi sawah. Ketersediaan air yang cukup memungkinkan petani menanam lebih dari sekali setahun dan menanam tanaman lainnya, intensitas tanam meningkat serta memungkinkan penggunaan varietas yang dianjurkan oleh pemerintah yang membawa implikasi terhadap perubahan produktivitas input yang digunakan.

Dengan pengelolaan air yang baik dalam arti memberikan sejumlah air yang tepat waktu dan jumlahnya sesuai dengan kebutuhan tanaman, serta didukung faktorfaktor lain maka akan tercapai hasil panen yang memuaskan yang akan berdampak pada peningkatan produksi. Gambaran di atas menunjukkan bahwa faktor produksi lahan, air dan tenaga kerja belum efisien, hal ini 
nampak dari ketersediaan faktor produksi yang belum dimanfaatkan secara optimal.

Tujuan dari penelitian ini ialah untuk menganalisa ketersediaan air, lahan dan tenaga kerja yang dimanfaatkan untuk usahatani padi sawah di Kecamatan Kupang Tengah. Untuk menganalisis efisiensi pemanfaatan air, lahan dan tenaga kerja terhadap produksi usahatani padi sawah di Kecamatan Kupang Tengah.

\section{METODE PENELITIAN}

Metode penentuan sampel dilakukan melalui dua tahap yakni: penentuan daerah penelitian yakni Desa Noelbaki merupakan daerah irigasi yang memiliki lahan potensial khususnya usahatani padi sawah. Penentuan responden menggunakan metode acak sederhana. Penentuan jumlah responden diambil $10 \%$ dari total populasi petani padi sawah, jadi jumlah responden sebanyak 50 orang. Selanjutnya dalam pengambilan sampel peneliti hanya memfokuskan pada petani yang memanfaatkan air dari saluran irigasi untuk usahatani tanaman padi sawah. Sedangkan untuk menentukan titik sampel debit air peneliti menggunakan 4 titik sampel.

\section{HASIL DAN PEMBAHASAN}

\section{Analisa Ketersediaan Sarana Produksi}

Sarana produksi yang digunakan untuk kegiatan usahatani padi sawah meliputi air, lahan, tenaga kerja, input (benih, pupuk, pestisida) dan peralatan pertanian.

Air

Untuk kebutuhan pemanfaatan air dan pengukuran air irigasi dilakukan pada 4 titik sampel yakni titik pertama tepat di depan pintu utama, titik kedua di pintu air kedua di mana terdapat 2 saluran yakni ke sawah dan ke saluran untuk pintu air ke tiga, titik ketiga di pintu air ke tiga yang digunakan ke lahan petani sedangkan titik keempat langsung ke sawah petani. Untuk mengetahui ketersediaan air irigasi diperlukan data yang cukup panjang dan handal, sehingga informasi keragaman debit terhadap waktu kejadian debit rendah dan tinggi dapat tercakup dan mewakili kejadian-kejadian tersebut. Namun karena keterbatasan waktu maka peneliti hanya mengukur ketersediaan air berdasarkan debit air di titik 1, titik 2 , titik 3 dan titik ke 4

\section{Ketersediaan Air di Saluran Irigasi}

Sub Daerah Irigasi Noelbaki adalah merupakan salah satu dari 6 Sub Daerah Irigasi yang terletak di Desa Noelbaki. Lokasi Penelitian ini termasuk pada Sub DI Noelbaki yang memiliki lahan sawah seluas 285 hektar dengan memanfaatkan air irigasi. Debit air yang dialirkan dari bendungan menuju ke Sub Daerah Irigasi Noelbaki rata-rata 358 liter/detik yang dapat dimanfaaatkan oleh petani pemakai air.

Berdasarkan hasil penelitian sebelumnya debit air di Kali Dendeng sebelum mendapat suplay air dari bendungan tilong sebesar 60 liter/detik (Suliswati, 2003). Debit air yang mengalir lewat bangunan ukur dan saluran Suplesi Noelbaki yakni kurang lebih 78 liter/detik. Air dari saluran irigasi tersebut hanya dipakai untuk mengairi lahan persawahan, karena mudah untuk diairi ke lahan.

Alur irigasi di Sub DI Noelbaki yakni sumber air irigasi yang berasal dari bendungan tilong melewati Sub di Noelbaki, dan masuk ke kali Dendeng dan mengalirkan air ke saluran utama bendungan, dan disalurkan ke daerah persawahan lewat saluran pintu pembagi air yang terdiri dari sub 1 sampai dengan sub 4 yang kemudian langsung disalurkan masuk ke pematangpematang sawah petani (memberikan air pada tanaman padi sawah) yang kemudian sisa dari kelebihan air langsung dibuang ke saluran pembuangan melewati kelompok tani usaha bersama di dusun Oekateta yang akhirnya dibuang ke laut.

Berdasarkan hasil wawancara dengan petani responden yakni respon petani sebagai pemakai air mengenai pemanfaatan air dari saluran irigasi, pada umumnya petani sangat mendukung bahwa dengan adanya saluran irigasi dapat memberikan dampak positif bagi keberlangsungan usahatani padi sawah.

Debit air di saluran irigasi diperoleh dengan pengukuran terhadap jumlah air yang tertampung di saluran per satuan waktu. Peneliti melakukan pengukuran pada 4 titik sampel dengan pengulangan 2 kali 
pengukuran yakni waktu pengukuran dilakukan pada pagi dan siang hari.

Tabel 1

Perhitungan Debit Air pada Saluran Irigasi

\begin{tabular}{|c|c|c|c|}
\hline $\begin{array}{c}\text { Titik } \\
\text { Pengukuran } \\
\text { Air }\end{array}$ & $\begin{array}{c}\text { Jumlah } \\
\text { (ml) }\end{array}$ & $\begin{array}{c}\text { Waktu } \\
\text { (detik) }\end{array}$ & $\begin{array}{c}\text { Debit Air } \\
\text { (ml/ detik) }\end{array}$ \\
\hline Titik 1 & 1230 & 14,87 & 82,72 \\
\hline Titik 2 & 1128 & 16,72 & 67,46 \\
\hline Titik 3 & 1050 & 17,23 & 60,94 \\
\hline Titik 4 & 1200 & 19,91 & 60,27 \\
\hline
\end{tabular}

Sumber : Hasil Penelitian

Berdasarkan Tabel 1 dapat dijelaskan bahwa debit air mulai dari titik 1 hingga titik 4 mengalami penurunan hal ini disebabkan oleh beberapa faktor diantaranya: (1) penguapan, (2) penggunaan air oleh masyarakat di sekitar saluran irigasi baik untuk kegiatan rumah tangga maupun untuk usahatani. Dari tabel 4.10 juga dapat dijelaskan bahwa debit air yang mulai menurun dari titik 1 hingga titik 4 tidak berdampak negatif terhadap ketersediaan air bagi usahatani padi sawah karena jumlah air yang tersedia lebih banyak dari kebutuhan air bagi tanaman padi sawah. Untuk usaha pertanian di lokasi tersebut, air sangat cukup sehingga petani akan membuang kelebihan air ke saluran khusus pembuangan yang kemudian air tersebut terbuang ke laut.

Untuk mengetahui volume air pada masing-masing titik yakni peneliti mengukur panjang, lebar dan tinggi saluran irigasi.

Tabel 2

Rata-Rata Volume Air pada Saluran Irigasi

\begin{tabular}{|c|c|c|c|c|}
\hline $\begin{array}{c}\text { Titik } \\
\text { Pengukuran } \\
\text { air }\end{array}$ & $\begin{array}{c}\text { Panjang } \\
(\mathrm{cm})\end{array}$ & $\begin{array}{c}\text { Lebar } \\
(\mathrm{cm})\end{array}$ & $\begin{array}{c}\text { Tinggi } \\
(\mathrm{cm})\end{array}$ & $\begin{array}{c}\text { Volume } \\
\left(\mathrm{cm}^{3}\right)\end{array}$ \\
\hline Titik 1 & 100 & 147 & 127 & 1.866 .900 \\
\hline Titik 2 & 100 & 131 & 118 & 1.545 .800 \\
\hline Titik 3 & 100 & 86 & 47 & 404.200 \\
\hline Titik 4 & 100 & 61 & 30 & 183.000 \\
\hline
\end{tabular}

Sumber : Hasil Penelitian

Tabel 2 dapat dijelaskan bahwa ratarata volume air mulai menurun dari titik 1 hingga titik 4, namun hal ini tidak berdampak negatif terhadap ketersediaan air bagi usahatani padi sawah karena jumlah air yang tersedia lebih banyak dari kebutuhan air bagi tanaman padi.

\section{Sistem Pembagian Air}

Untuk mengairi sawah, petani di lokasi penelitian memanfaatkan air dari saluran irigasi yang diperoleh secara gratis (tidak mengeluarkan biaya). Selama ini di lokasi penelitian menyangkut sistem pembagian air memang tidak ada kendala yang berarti karena lewat suatu program bersama yang diatur dalam kelompok, sehingga waktu tanam padi sawah di lokasi tersebut dilakukan secara serentak oleh petani sehingga mudah dalam pelayanan air irigasi.

Berdasarkan hasil penelitian ratarata pada musim tanam pertama petani mengusahakan padi saja. Hal ini disebabkan pada musim tanam pertama pada bulanbulan tersebut persediaan air meningkat (musim hujan). Pada saat musim hujan di mana keadaan air melimpah sistem pembagian air ke petani dilakukan secara merata langsung diairi ke lahan persawahan.

Pada saat menjelang musim kemarau apabila terjadi penurunan debit air maka sistem pembagian air dilakukan dengan menggunakan jadwal pembagian air secara bergiliran berdasarkan sub-sub yang ada dengan melewati saluran yang langsung ke pematang-pematang sawah petani. Dengan menerapkan sistem ulu-ulu, maka frekwensi air yang diairi ke dalam sawah terus dikontrol atau diawasi oleh petugas penjaga pintu air. Umumnya air yang dialirkan ke saluran pematang sawah tergantung dari permintaan petani. Jika air di pematang sudah cukup maka petani dapat menutup air sehingga air dapat mengalir ke lahan petani yang lain 
Tabel 3

Penggunaan Air Berdasarkan Tahapan Kegiatan Usahatani Padi Sawah di Desa Noel baki Tahun 2013.

\begin{tabular}{|l|c|c|c|c|}
\hline $\begin{array}{l}\text { Tahapan Kegiatan } \\
\text { Usahatani }\end{array}$ & $\begin{array}{l}\text { Besaran waktu } \\
\text { yang digunakan } \\
\text { (detik) }\end{array}$ & $\begin{array}{c}\text { Debit air } \\
(\mathrm{ml} / \text { detik) }\end{array}$ & $\begin{array}{l}\text { Jumlah air yang } \\
\text { digunakan (ml) }\end{array}$ & $\begin{array}{l}\text { Jumlah air yang } \\
\text { digunakan (L) }\end{array}$ \\
\hline Pengolahan lahan & 43.200 & 60.27 & 2.603 .664 & 2.603 .66 \\
\hline Penanaman & 144.000 & 60.27 & 8.678 .880 & 8.678 .88 \\
\hline Pemeliharaan & 936.000 & 60.27 & 56.412 .720 & 56.412 .72 \\
\hline Panen & 10.800 & 60.27 & 650.916 & 650.92 \\
\hline $\begin{array}{l}\text { Total penggunaan } \\
\text { air per 1 hektar } \\
\text { lahan sawah }\end{array}$ & 1.134 .000 & 241 & 68.346 .180 & 68.346 \\
\hline
\end{tabular}

Sumber : Hasil penelitian

Berdasarkan Tabel 3 dapat dijelaskan bahwa rata-rata penggunaan air untuk usahatani tanaman padi sawah di lokasi penelitian per 1 ha lahan yakni 68.346 liter. Besaran waktu yang digunakan untuk usahatani diperoleh dengan perkalian antara lamanya waktu pembukaan air dikalikan jumlah hari. Untuk itu diperoleh rata-rata waktu yang digunakan untuk usahatani padi sawah yakni 1.134.000 detik atau 9.450 jam.

Tabel 4

Kebutuhan Air untuk Tanaman Padi Sesuai dengan Tahap Pertumbuhan

\begin{tabular}{|c|c|c|c|c|}
\hline \multirow[b]{2}{*}{ No } & \multirow[b]{2}{*}{$\begin{array}{l}\text { Tahap Kegiatan } \\
\text { (pertumbuhan) }\end{array}$} & \multicolumn{3}{|c|}{ Varietas Unggul } \\
\hline & & Liter/ detik/ Ha & Periode (hari) & $\begin{array}{c}\text { Kebutuhan Air } \\
\text { (liter) }\end{array}$ \\
\hline 1 & Pengolahan tanah & 1.5 & 0 & 0 \\
\hline 2 & Pembibitan & 0.4 & 20 & 8 \\
\hline 3 & Tanam s/d Primodia & 0.75 & 35 & 26.25 \\
\hline 4 & Primodia s/ d Bunga & 0.9 & 20 & 18 \\
\hline 5 & Bunga s/d Penuh & 1 & 20 & 20 \\
\hline 6 & Penuh s/d Panen & 0.9 & 20 & 18 \\
\hline & Jumlah & 5.45 & 115 & 90.25 \\
\hline
\end{tabular}

Dengan membandingkan Tabel 3 dan Tabel 4 maka dapat diketahui bahwa jumlah kebutuhan air di lokasi penelitian berlebihan yakni sebesar 68.257,75 liter. Hal ini disebabkan karena (1) lahan yang diusahakan untuk usahatani padi yakni tanah latosol dimana pada umumnya tanah ini memiliki sifat penyerapan air yang mudah sampai agak sukar merembes air, oleh sebab itu infiltrasi dan perkolasinya dari agak cepat sampai agak lambat, sehingga dibutuhkan air yang cukup untuk pengolahan lahan, (2) kondisi topografi lahan dimana jika lahan tersebut memiliki topografi yang tinggi maka dibutuhkan waktu yang lama untuk air mencapai lahan

akan semakin lama, (3) tingginya tingkat evaporasi (penguapan) (4) rendahnya pengetahuan petani untuk mengetahui tingkat kebutuhan air yang tepat bagi tanaman padi.

\section{Luas Lahan Produktif}

Luas lahan produktif yakni besarnya lahan yang dimanfaatkan oleh petani untuk usahatani padi sawah. Di lokasi penelitian total luas lahan sawah yakni 285 ha, yang digarap dengan memanfaatkan air irigasi yakni 240 hektar. Sisa yang belum digarap yakni 45 ha. Tiap petani memiliki lahan yang hampir sama sehingga memungkinkan 
petani dalam pengaturan musim tanam yang serentak dan mudah dalam pelayanan air irigasi.

Tabel 5.

Luas Lahan Produktif yang Dimanfaatkan

Petani di Desa Noelbaki Tahun 2013.

\begin{tabular}{|l|l|c|c|}
\hline No & $\begin{array}{c}\text { Luas lahan } \\
\text { sawah }\end{array}$ & $\begin{array}{c}\text { Jumlah } \\
\text { (orang) }\end{array}$ & $\begin{array}{c}\text { Persentase } \\
(\%)\end{array}$ \\
\hline 1. & $\begin{array}{l}\text { Sempit (50 are } \\
-95 \text { are) }\end{array}$ & 28 & 56 \\
\hline 2. & Sedang (1 ha) & 22 & 44 \\
\hline 3. & Luas (>1 ha) & - & - \\
\hline \multicolumn{2}{|l|}{ Total } & 50 & 100 \\
\hline
\end{tabular}

Sumber : Hasil Penelitian

Dari Tabel 5 dapat dijelaskan bahwa rata- rata luas lahan petani bervariasi mulai dari 75 are sampai dengan 1 hektar. Dari luas lahan yang dimiliki rata-rata lahan yang dimanfaatkan petani sebesar 62,65\%. Rata-rata lahan yang dimanfaatkan oleh petani untuk melaksanakan usahatani yakni 97,24 are dengan penggunaan tertinggi 1 hektar dan terendah 75 are. Variasi pemanfaatan lahan oleh petani disebabkan perbedaan jumlah lahan yang dimiliki serta letak lahan yang berdekatan dengan saluran air irigasi.

Berdasarkan hasil penelitian sebagian besar petani memiliki luasan lahan garapan sebesar 50 are-95 are hal ini disebabkan karena pada umumnya lahan yang digarap merupakan tanah warisan. Sebagai akibat dari rendahnya luasan lahan yang digarap maka total produksi yang diperoleh belum optimal yang berdampak pada kontinuitas ketersediaan produksi padi di desa. Secara rinci status kepemilikan lahan petani responden dapat dilihat pada Tabel 6
Tabel 6.

Status Kepemilikan Lahan Petani di Desa Noelbaki Tahun 2013

\begin{tabular}{|l|l|l|}
\hline $\begin{array}{c}\text { Status Kepemilikan } \\
\text { Lahan }\end{array}$ & $\begin{array}{l}\text { Jumlah } \\
\text { (orang) }\end{array}$ & $\begin{array}{c}\text { Persentase } \\
(\%)\end{array}$ \\
\hline Pemilik penggarap & 35 & 70 \\
\hline Penggarap & 15 & 30 \\
\hline Jumlah & 50 & 100 \\
\hline
\end{tabular}

Sumber : Hasil Penelitian

Dari Tabel 6 dapat dijelaskan bahwa jika ditinjau dari status pengelolaan lahan usahatani padi sawah di lokasi penelitian sebagian besar yakni sebanyak 35 orang atau sebesar $70 \%$ berstatus sebagai pemilik penggarap sedangkan petani responden yang berstatus sebagai penggarap sebanyak 15 orang atau sebesar 30\% yang hanya mengelola lahan yang dimiliki oleh orang lain yang secara turun temurun ataupun lahan yang dibeli dari petani yang ada dalam hamparan sawah sebelumnya.

Berdasarkan hasil penelitian pemilik pengarap lebih dominan. Hal ini disebabkan jenis tanah yang ada di lokasi penelitian yakni tanah latosol di mana tanah ini cocok untuk usahatani padi sawah. Akibatnya produksi padi yang dihasilkan mampu memenuhi kebutuhan pangan petani.

\section{Tenaga Kerja}

Tenaga kerja merupakan jumlah tenaga kerja yang mengusahakan usahatani padi sawah selama satu musim tanam. Di lokasi penelitian petani menggunakan tenaga kerja dalam keluarga dan tenaga kerja luar keluarga. Tenaga kerja luar keluarga digunakan untuk mempercepat kegiatan penanaman serta pemanenan. Namun tenaga kerja luar keluarga tidak diberi upah karena menggunakan sistem gotong-royong.

Berdasarkan hasil penelitian adapun gambaran tenaga kerja yang terlibat dalam usahatani padi sawah berdasarkan tahapan kegiatan usahataninya yakni sebagai berikut: 
Gambar 1

Curahan Tenaga Kerja Pertahapan Usahatani di Desa Noel bakti tahun 2013

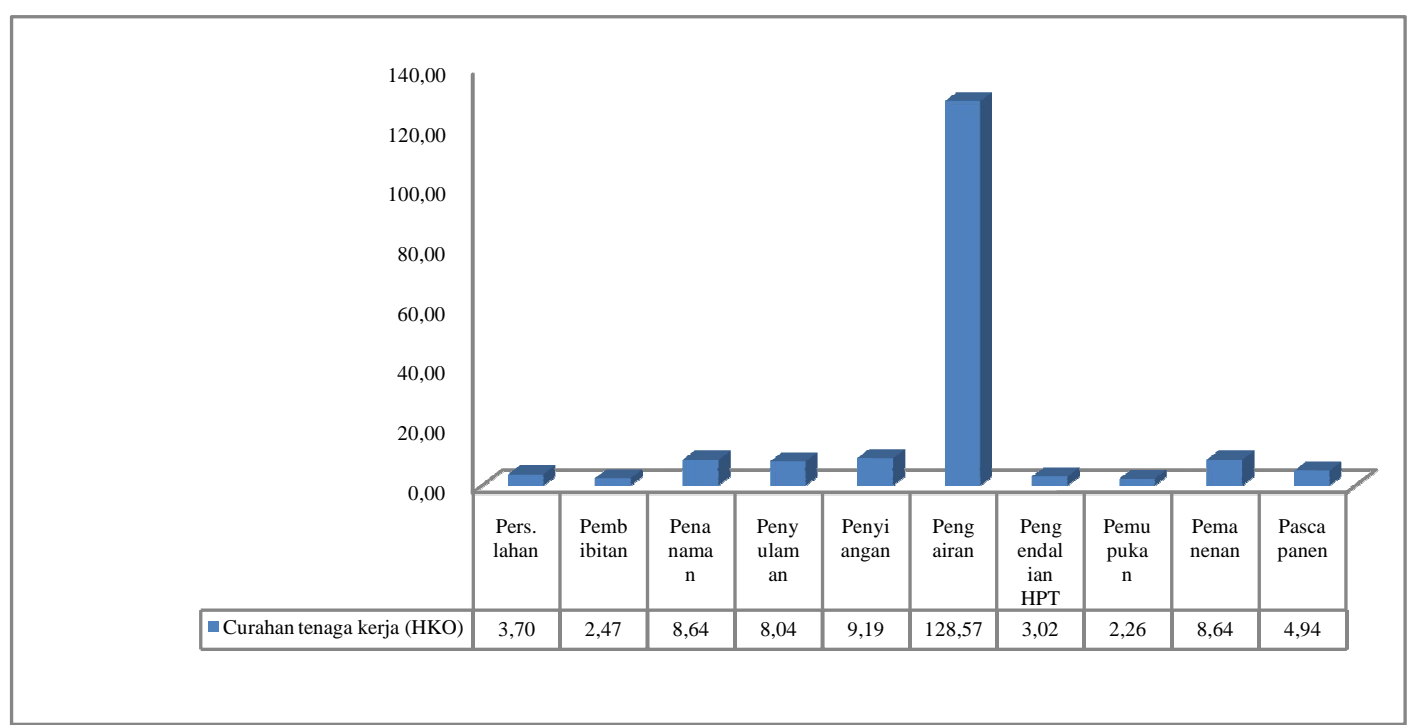

Gambar 1 dapat dijelaskan bahwa rata-rata curahan tenaga kerja yang digunakan adalah pada tahapan pengairan. Hal ini disebabkan pada tahapan ini petani dituntut untuk intesif memperhatikan jumlah air yang masuk ke sawah. Hal ini menggambarkan bahwa kebanyakan petani di daerah penelitian berusia produktif sehingga petani akan lebih mampu mengarap lahan yang lebih luas sehingga berdampak pada peningkatan produksi pangan. Selanjutnya jenis tanah latosol di

mana tanah ini mempunyai lapisan solum tanah yang tebal sampai sangat tebal, yaitu dari $130 \mathrm{~cm}$ sampai 5 meter bahkan lebih sehingga petani harus lebih insentif dalam kegiatan pengemburan lahan.

Input

Input yang digunakan oleh petani di lokasi penelitian yakni bibit, pupuk dan pestisida. Rata-rata penggunaan input dapat dilihat pada Tabel 7.

Tabel 7

Rata-rata jenis input yang digunakan petani untuk usahatani padi sawah di Desa Noel baki tahun 2013.

\begin{tabular}{|c|c|}
\hline Jenisinput & $\begin{array}{c}\text { Rata-rata } \\
\text { Penggunaan }\end{array}$ \\
\hline Benih (ciherang) & $21,8 \mathrm{~kg}$ \\
\hline Pupuk & \\
Urea & $190 \mathrm{~kg}$ \\
KCl & $34,8 \mathrm{~kg}$ \\
SP36 & $40,2 \mathrm{~kg}$ \\
NPK & $258 \mathrm{~kg}$ \\
\hline Pestisida & \\
Foltus/ Brantas & 1 liter \\
\hline
\end{tabular}

Sumber : Hasil Penelitian

Dari Tabel 7 dapat dijelaskan bahwa rata-rata penggunaan benih yakni $21,8 \mathrm{~kg}$ per rata-rata luas lahan 97,24 are sehingga 48 untuk 1 ha dibutuhkan benih 22,4 kg. Besaran pengunaan benih jika dibandingkan dengan rata-rata penggunaan 
benih yang dianjurkan (25 kg/ha) maka penggunaan benih di lokasi penelitian masih dapat ditingkatkan. Kekurangan penggunaan benih di lokasi penelitian yakni sebesar 2,6 Kg hal ini disebabkan karena (1) petani tidak memperhatikan jarak tanam yang dianjurkan yakni $(25 \times 25 \mathrm{~cm})$,

(2) bentuk lahan petani yang tidak lurus. Kekuranagan penggunaan benih di lokasi penelitian akan berdampak pada rendahnya produktifitas lahan dan produksi padi sawah.

Rata-rata penggunaan pupuk urea per ha yakni $190 \mathrm{~kg}$ per rata-rata luas lahan 97,24 are sehingga untuk 1 ha dibutuhkan pupuk urea sebesar 195,39 kg. Besaran penggunaan pupuk urea jika dibandingkan dengan rata-rata penggunaan pupuk urea yang dianjurkan $(250 \mathrm{~kg})$ per hektar maka penggunaan pupuk urea di lokasi penelitian lebih sedikit yakni sebesar 54,6 kg, hal ini disebabkan karena (1) rendahnya pengetahuan petani tentang kadar nitrogen yang dibutuhkan oleh tanaman padi sehingga petani tidak mampu mengkombinasikan pupuk urea dengan pupuk lain yang mengandung nitrogen seperti pupuk NPK Ponska, (2) rendahnya modal yang dimiliki (3) minimnya ketersediaan pupuk urea di pasaran.

Rata-rata penggunaan pupuk Kcl per ha yakni $34,8 \mathrm{~kg}$ per rata-rata luas lahan 97,24 are sehingga untuk 1 Ha dibutuhkan pupuk Kcl sebesar 35,78 kg. Besaran pengunaan Kcl jika dibandingkan dengan rata-rata penggunaan pupuk Kcl yang dianjurkan $(75 \mathrm{~kg})$ maka penggunaan pupuk Kcl di lokasi penelitian yakni lebih sedikit sebesar 39,21 kg, hal ini disebabkan karena (1) rendahnya pengetahuan petani tentang kadar K2O yang dibutuhkan oleh tanaman padi, (2) rendahnya pengetahuan petani tentang kadar K2O yang terkandung dalam jenis pupuk yang digunakan. Dampak yang ditimbulkan dari rendahnya penggunaan pupuk menyebabkan rendahnya produksi padi yang diperoleh, hal ini disebabkan karena jenis tanah di lokasi penelitian yakni tanah latosol di mana jenis tanah ini memiliki kadar unsur hara dan organiknya rendah.

\section{Produksi Padi Sawah}

Produksi merupakan hasil fisik yang diperoleh petani dalam melakukan usahatani padi sawah. Rata-rata hasil fisik tanaman yang diusahakan mengalami peningkatan. Hasil penelitian menunjukan bahwa petani di lokasi penelitian sangat mendukung dengan adanya air dari saluran irigasi hal ini tentunya sangat membantu petani dalam melakukan kegiatan usahatani yang lebih baik sehingga produksi diharapkan dapat mengalami peningkatan dari tahun ke tahun.

Dengan adanya peningkatan produksi maka ketersediaan pangan tentunya untuk keluarga juga meningkat. Bagi petani pemilik penggarap yang memiliki hand traktor total hasil panen akan dimiliki sendiri sedangkan bagi petani penggarap setelah selesai musim tanam, total hasil panen akan dibagi dalam 3 bagian yakni (pemilik lahan, pemilik traktor dan penggarap).

Berdasarkan hasil penelitian ratarata produksi padi untuk musim tanam pertama yakni 3,656 ton/ha. Dari hasil wawancara rata-rata produksi padi sawah sampai dengan musim tanam Januari 2013 mengalami penurunan, salah satunya dipengaruhi oleh keterlambatan dalam pengolahan lahan, juga karena faktor pemupukan karena pada saat tahap pemberian pupuk, sama sekali persediaan pupuk kehabisan stoknya di pasar, sehingga terjadi kelangkaan pupuk, tanaman mengalami keterlambatan dalam pemberian pupuk.

Analisis Efisiensi Penggunaan Air, Lahan dan Tenaga Kerja terhadap Produksi Usahatani Padi Sawah.

Untuk menganalisis efisiensi penggunaan air, lahan dan tenaga kerja terhadap produksi usahatani padi sawah peneliti menggunakan model regresi linear berganda dengan fungsi Coob-douglas.Hasil Analisis secara rinci dapat dilihat pada Tabel 8. 
Tabel 8.

Hasil Analisis Pengaruh Pemanfataan Air, Lahan dan Tenaga kerja terhadap Produksi Usahatani Padi Sawah di Desa Noel baki Tahun 2013.

\begin{tabular}{|c|l|l|l|l|l|}
\hline No & \multicolumn{1}{|c|}{ Variabel } & \multicolumn{1}{|c|}{ Coefficients } & Std. Error & t-Statistic & Sig. \\
\hline 1. & C (bo) & 6.7481 & 20.114 & 3.355 & .002 \\
\hline 2. & Air (ml) & -6.018 & 1.925 & -3.126 & .003 \\
\hline 3. & $\begin{array}{l}\text { Luas lahan } \\
\text { (are) }\end{array}$ & .095 & .022 & 4.317 & .000 \\
\hline 4. & $\begin{array}{l}\text { Tenaga kerja } \\
\text { (HKO) }\end{array}$ & .146 & .084 & 1.729 & .091 \\
\hline 5. & R-squared & .979 & \\
\hline 6. & Adjusted R- squared & .978 & \\
\hline 7. & Std. Error of the Estimate & .04383 & \\
\hline 8. & F-statistic & 722.352 & $.000 \mathrm{~b}$ & \\
\hline 9. & Prob (F-statistic) & & & \\
\hline
\end{tabular}

Sumber : Hasil Penelitian

Dari Tabel 8 menunjukkan bahwa nilai F hitung sebesar 722,352 lebih besar dari nilai $\mathrm{F}$ tabel pada tingkat kepercayaan $99 \%$. Hal ini berarti bahwa produksi padi sawah dipengaruhi secara bersama-sama oleh pemanfaatan air, lahan dan tenaga kerja. Besarnya keragaman variabel produksi padi sawah yang dapat dijelaskan oleh variabel pemanfaatan air, lahan dan tenaga kerja. Hasil analisis menunjukkan oleh besarnya nilai koefisien determinasi $\left(R^{2}\right)$. Nilai sebesar 0,979 yang berarti bahwa 97,09\% keragaman variabel produksi padi sawah yang dimasukkan dalam model dapat menjelaskan keragaman variabel pemanfaatan air, lahan dan tenaga kerja. Sedangkan 2,91 \% diterangkan oleh variabel lain di luar model.

Untuk mengetahui variabel independen yang nyata pengaruhnya terhadap produksi padi sawah digunakan uji t. Hasil analisis dengan menggunakan uji t dua arah menunjukkan bahwa variabel luas lahan berpengaruh nyata terhadap produksi padi sawah pada tingkat kepercayaan 99\%, sedangkan pemanfaatan air berpengaruh nyata terhadap produksi padi sawah pada taraf $95 \%$. Selanjutnya variabel tenaga kerja berpengaruh nyata terhadap produksi padi sawah pada taraf $90 \%$.
Hasil analisis menunjukkan bahwa

nilai $\mathrm{b}_{0}$ bernilai positif 6,7481 hal ini berarti

bahwa pada saat variabel pemanfaatan air, lahan dan tenaga kerja sama dengan nol maka produksi padi sawah sebesar $6,7481 \mathrm{~kg}$.

Nilai koefisien regresi $b_{1}$ sebesar negatif 6,016 hal ini berarti bahwa jika penggunaan air ditingkatkan sebesar $1 \mathrm{ml}$ maka produksi padi sawah akan menurun sebesar 6,061 kg. Ini berarti bahwa penggunaan air oleh petani di desa Noelbaki berlebihan, hal ini senada dengan anjuran penggunaan air untuk padi sawah menurut kebutuhan air irigasi (PT1) (2000) yakni 90,25 liter atau $90.250 \mathrm{ml}$.

Nilai koefisien regresi $b_{2}$ sebesar positif 0,095 hal ini berarti bahwa jika pemanfaatan luas lahan ditingkatkan sebesar 1 are maka produksi padi sawah akan meningkat sebesar 0,095 kg. Hal ini berarti bahwa pemanfaatan luas lahan oleh petani di desa Noelbaki masih harus ditingkatkan untuk mengoptimalkan produksi padi sawah.

Nilai koefisien regresi $b_{3}$ sebesar positif 0,146 hal ini berarti bahwa jika pemanfaatan tenaga kerja ditingkatkan sebesar $1 \mathrm{HKO}$ maka produksi padi sawah akan meningkat sebesar 0,146 kg. Hal ini berarti bahwa pemanfaatan tenaga kerja oleh petani di desa Noelbaki masih harus 
ditingkatkan untuk mengoptimalkan produksi padi sawah.

Berdasarkan hasil analisis diperoleh model fungsi produksi padi sawah yakni :

\section{$Y=\operatorname{Ln} 6.7481-6.018 \operatorname{Ln} X 1+0.095 \operatorname{LnX} 2+$ $0.146 \mathrm{LnX3}$}

Fungsi dengan model regresi berganda kemudian ditransfer ke model coob douglas

$$
\mathrm{Y}=852,437 \mathrm{X}_{1}^{-410.75} \mathrm{X}_{2}{ }^{1.099} \mathrm{X}_{3} 1.157
$$

Fungsi tersebut diturunkan untuk mengetahui nilai koefisien efisiensi dari air, lahan dan tenaga kerja.

Hasil uji t untuk variabel pemanfaatan air, lahan dan tenaga kerja di lokasi penelitian belumlah efisien dan nyata pada taraf kepercayaan $1 \%$.Hasil analisis efisiensi pemanfaatan air untuk usahatani padi sawah tidaklah efisien. Untuk itu agar efisien maka petani harus mengurangi jumlah pemakaian air (nilai NPMxi/ Px < 1) sebesar 83.829,24 liter, hal ini seiring dengan model pada fungsi produksi dimana jika petani ingin terus meningkatkan jumlah air yang digunakan maka produksi padi sawah akan menurun.

Beberapa faktor yang menyebabkan belum efisiennya pemanfaatan air yakni (1) rendahnya pengetahuan petani mengenai kebutuhan air yang tepat bagi tanaman padi (2) jenis tanah di lokasi penelitian yakni jenis tanah latosol yang memiliki sifat pada umumnya mudah sampai agak sukar merembes air, oleh sebab itu infiltrasi dan per kolasinya dari agak cepat sampai agak lambat, daya menahan air cukup baik dan agak tahan terhadap erosi.

Berdasarkan hasil analisis efisiensi pemanfaatan lahan untuk usahatani padi sawah masih dapat ditingkatkan karena belumlah efisien (nilai NPMxi/ Px > 1) untuk itu petani harus meningkatkan luas lahan yang diusahakan yakni sebesar 1,5 are. Hal ini disebabkan karena petani tidak memiliki modal yang cukup dan keterbatasan tenaga kerja dalam mengusahakan lahan yang dimiliki untuk usahatani padi sawah sehingga alternatif yang digunakan petani yakni menyewakan lahan tersebut.

Pemanfaatan tenaga kerja untuk usahatani padi sawah di lokasi penelitian belumlah efisien (nilai NPMXi/PX > 1) untuk itu petani harus meningkatkan curahan tenaga kerja yakni sebesar 0,175 $\mathrm{HKO}$, hal ini terjadi karena terdapat tenaga kerja dalam rumah tangga petani yang tidak aktif dalam usahatani melainkan memilih untuk usaha lain seperti ojek dan berjualan daripada harus bekerja di sawah.

\section{KESIMPULAN}

Berdasarkan hasil penelitian maka dapat disimpulkan bahwa :

1. Ketersediaan air dapat diketahui melalui perhitungan debit air pada saluran irigasi. Debit air mengalami penurunan dari titik 1 hingga titik 4 namun hal ini tidak berdampak negatif terhadap ketersediaan air bagi usahatani padi sawah karena jumlah air yang tersedia lebih banyak dari kebutuhan air bagi tanaman padi sawah. Ketersediaan luas lahan petani bervariasi mulai dari 75 are sampai dengan 1 hektar, untuk ketersediaan lahan yang dimanfaatkan petani yakni sebesar 62,65 \%, sedangkan ketersediaan tenaga kerja yakni rata-rata curahan tenaga kerja yang digunakan adalah 179,468 HKO. Hal ini disebabkan pada tahapan ini petani dituntut untuk intensif memperhatikan jumlah air yang masuk ke sawah.

2. Hasil analisis efisiensi pemanfaatan air di lokasi penelitian belumlah efisien. Untuk itu agar efisien maka petani harus mengurangi jumlah pemakaian air. Untuk pemanfaatan lahan pada usahatani padi sawah perlu ditingkatkan karena belumlah efisien, sedangkan pemanfaatan tenaga kerja untuk usahatani padi sawah di lokasi penelitian juga belumlah efisien untuk itu perlu ditingkatkan. 
DAFTAR PUSTAKA

-------,2000. Sistem Irigasi Seri Modul

IRI, Semarang

Anonimous, 2001. Pengembangan Air

Tanah Dan Permasalahannya.

Depertemen Pekerjaan Umum.

Kupang.

----------. 2010. Rencana Pembangunan Pertanian 2005-2009.

Bank Indonesia. 2008. Annual Report Of Bank Indonesia 2008.

Depertemen Pemukiman dan Pengembangan Wilayah-Dirjen Pengembangan Perdesaan proyek Irigasi jawa tengah. 2000. Kebutuhan air irigasi- Seri Modul PTI, Semarang,

Naisanu J., Agustinus Nubatonis. 2013. Naisanu Joritha, 2009. Minimisasi Usahatani Tanaman Pangan Di Lokasi Sumur Bor Kabupaten Kupang. Tesis.UGM.

Susilawati S. 2003. Kajian Pemanfaatan Air Waduk Tilong Untuk Irigasi Pertanian. Hasil Penelitian - Fakultas Teknik Universitas Widya Mandira Kupang. 